\title{
Key Challenges facing Online Dispute Resolution in Saudi Arabia
}

\author{
Dr. Mohammad Alharbi \\ SJD Suffolk University Law School \\ PO box 3540, Jeddah 23741, Saudi Arabia
}

\begin{abstract}
Online Dispute Resolution (ODR) has emerged as a particularly effective means to resolve various forms of commercial disputes. This dispute resolution mechanism now employs an array of technologies to resolve both domestic and international commercial disputes. Courts in some jurisdictions have piloted successful ODR programs, although others are still struggling to find balance between traditional litigation tools and ODR.The advancement in technology has most significantly changed traditional arbitral procedures and practices. With the panoply of ODR options, cyberspace is a new venue for arbitration in the international arena. Successful examples of ODR demonstrate arbitration that is conducted fully through electronic means from the onset to the conclusion. This paper examines the case of Saudi Arabia, where there have been attempts to provide a regulatory framework for online dispute resolution. These strides are still minimal, given the challenges of ODR as applied in the present Saudi Arabian legal structure.Saudi Arabia presents unique challenges. The country's legal system is premised on Shari'a law, which significantly defines the culture and the rules for Saudi Arabian people. Integrating an online dispute resolution system into the Shari'a legal construct could create a business environment for both Saudis and foreigners to facilitate smooth commercial transactions and to address related disputes when they arise. Finding a way to align ODR with Shari'a law, however, is the task. Obstacles include: the lack of legal certainty and government regulations that could provide guidance in the area of ODR; the lack of legitimacy; and the lack of awareness concerning the use of online systems. This paper will examine these Challenges and, in particular, focus on the existing Saudi Arabian legal framework for dispute resolution in relation to Shari'a law and theorize how ODR might be incorporated in future commercial arbitrations.
\end{abstract}

Keywords: Sharia Law, Arbitration, Alternative Dispute Resolution, Online Dispute Resolution, Public Policy.

DOI: $10.7176 / \mathrm{JLPG} / 88-11$

Publication date: August $31^{\text {st }} 2019$

\section{Introduction}

The onset of the 21 st century has seen the global spread of commercial disputes and conflicts, from traditional disagreements with parties present within clear jurisdictional boundaries to new online skirmishes with jurisdictional and logistical questions. For traditional disputes, resolution frameworks and legal platforms are already in place. This has not been the case for online disputes.

The explosive expansion of internet use has made it possible for business enterprises to expand their markets and concentrate services to enormous groups of e-consumers. Online commercial activities can result in disagreements similar to traditional transactions and need similar legal stability and predictable legal resolutions. ${ }^{1}$ It is thus vital for adequate legal frameworks - and related technology infrastructure - to be implemented to resolve online disputes and to ensure that participating in all forms of online commercial activities can be safe and secure. Uncertainty over the legal framework for e-disputes might eventually limit the capacity of both companies to enter the e-market and consumers to purchase products and services online. ${ }^{2}$ This This has not yet been the case, as online transactions and corollary disputes are increasing in both magnitude and frequency.

That increase, however, does necessitate the emergence of online dispute resolution (ODR) systems. ODR is an alternative process to traditional dispute resolution, employing technology to find solutions to claims or disputes. $^{3}$ ODR can find solutions to disputes taking place online, or those emanating from e-commerce transactions or further clashes not involving the internet, commonly referred to as "offline" disputes. ${ }^{4}$ This process offers flexible options to the customary legal process or method of dispute resolution, typically using a court and its resources, or a judge, arbitrator, or mediator.

ODR may involve parties in arbitration, mediation, or negotiation, and uses internet or web-based technologies to resolve their disputes. This process can take place exclusively online using video conferencing or email, or both. ${ }^{5}$ In certain cases, parties can agree to meet offline. Both online and offline methods can be

\footnotetext{
${ }^{1}$ Julia Hornell, Internet Disputes, Cross-Border Internet Dispute Resolution 19-46 (2009).

${ }^{2}$ Farzaneh Badiei, Using Online Arbitration in E-Commerce Disputes, 2 InT'L J. ON ONLINE DiSP. RESOL. 13 (2015).

${ }^{3}$ Kenneth McCulloch, Alternative Dispute Resolution Techniques: Pros and Cons, 11 EMP. REL. TODAY 311-319 (1984).

${ }^{4}$ Karolina Mania, Online Dispute Resolution: The Future of Justice, 1 INT'L COMP. JURIS. 77 (2015).

${ }^{5}$ Stephanie Bol, Ethan Katsh \& Janet Rifkin, Online Dispute Resolution, Resolving Conflicts in Cyberspace, 11 ARTIFICIAL INTELLIGENCE \& \& L. 69 (2003).
} 
combined. The rising number of online business transactions (e-commerce) has spurred the emergence of ODR organizations offering services to businesses and their customers. This is attributable to ODR's advantages of generally being less expensive compared to traditional conflict resolution, more efficient in timing and scheduling, and more flexible geographically. ${ }^{1}$ Some e-commerce companies also offer ODR themselves as a service to their clients. ${ }^{2}$

Globally, commercial dispute resolution takes place in various ways, using litigation and other alternative dispute resolution (ADR) systems. The first method - which is always available to parties in a dispute - is negotiation, which is a voluntary and informal process. Negotiations may or may not involve the representation of the disputing parties by their attorneys. ${ }^{3}$ It is worth noting that for some ODR systems the parties normally do not seek assistance from attorneys. There is no neutral third party in this form of online dispute resolution. However, all the other characteristics of online dispute resolution are similar, using online or in-person communication. Some ODR providers assist parties to negotiate online through a process called "blind bidding," which permits a party to make a hidden settlement bid by computer. In some instances, the computer system combines the suggestions of both parties and announces a settlement criterion based on both parties' wishes. ${ }^{4}$

The second common method for resolving disputes is through litigation, which is the most common method in both the public and private sectors. ${ }^{5}$ Litigation relies on a country's judicial system. Its formal process is complex and depends on a substantial array of procedural requirements and legal rules. Parties typically seek the assistance of lawyers. Judicial proceedings are often publicly conducted and can invite scrutiny from commercial competitors interested in the particulars of the dispute. Although the process is slow, expensive, and dependent upon a stringent system of rules of procedure and evidence, tradition, familiarity, and dependability can make it preferable to alternative dispute resolution methods. Those attributes, however, can make litigation less flexible or desirable than online dispute resolution. ${ }^{6}$

A third method is mediation, which is a private and voluntary process. The parties are assisted in discussing and resolving their disputes by a neutral third party - the mediator. Each party can collect and present evidence that they have been wronged and propose their desired resolution. The mediator works to achieve a settlement - a new agreement - between the parties. Mediation has also now been effectively used in ODR. ${ }^{7}$ Although the whole process can entirely be done online - through video conferencing or email - the parties may also arrange to physically meet in person. Some ODR methods utilize both methods. The mediator helps the parties to set rules that help them identify points and issues where they either agree or disagree, but does not make decisions on behalf of the parties in dispute. ${ }^{8}$ The mediator can also evaluate the rules and - with the parties' consent - suggest possible resolutions while still leaving the parties with the responsibility of resolving the dispute. If the parties agree, they complete a written agreement with specific details of the settlement, which forms a new agreement (contract) between them. In most cases, these can be enforced in a court of law.

The fourth method is arbitration, where the resolution of a dispute is decided by a third party - e.g., one or more arbitrators - after scrutinizing the available evidence and hearing each party's arguments. Unlike mediation, where the resolution of the dispute is primarily dependent upon the disputing parties, the neutral arbitrator in arbitration has the authority to make a decision regarding the dispute. Arbitration is less formal compared to traditional litigation, with fewer procedural rules, and usually takes less time. This process can take place exclusively online or a meeting in person can be arranged between the parties in the dispute. ${ }^{9}$

Arbitration is unique in that it can be either binding or non-binding. ${ }^{10}$ Some countries discourage their consumers from submitting to binding arbitration. In binding arbitration, the parties must adhere to the arbitrator's decision. That decision is enforceable in a court of law. ${ }^{11}$ In a non-binding arbitration, the parties are under no obligation to follow the arbitrator's decision, as the latter's role is advisory rather than authoritative. Nevertheless, a non-binding decision can still be enforced in court if the parties have agreed to it. ${ }^{12}$

\footnotetext{
${ }^{1}$ Benyekhlef Karim \& Gélinas Fabien, Dispute Resolution, A MANUAL OF InTERNATIONAL DispuTE RESOLUTION 13 (2006).

2 Julie Zetler, Litigation and Dispute Resolution, EsSENTIALS OF LAW, ETHICS, AND PROFESSIONAL ISSUES IN CAM 45 (2012).

${ }^{3}$ Daniel Bar-Tal, From Intractable Conflict through Conflict Resolution to Reconciliation: Psychological Analysis, 21 POL. PsychOL. 353 (2000).

${ }^{4} I d$.

${ }^{5}$ Osama Jannadia et al., Contractual Methods for Dispute Avoidance and Resolution (DAR), 18 INT'L J. OF PROJECT MGMT 43 (2000).

${ }^{6} \mathrm{Id}$. at 46 .

${ }^{7}$ Jacques De Werra, ADR in Cyberspace: The Need to Adopt Global Alternative Dispute Resolution Mechanisms for Addressing the Challenges of Massive Online Micro-Justice, 2 SSRN ELEC. J. 81 (2016).

${ }^{8}$ Stephanie Bol, Ethan Katsh \& Janet Rifkin, Online Dispute Resolution, Resolving Conflicts in Cyberspace, 11 ARTIFICIAL InTELLIGENCE \& L. 70(2003).

${ }^{9}$ Tania Sourdin \& Alan Shanks, Evaluating ADR in ATO Disputes -- Executive Summary, SSRN ELEC. J. 61 (2015).

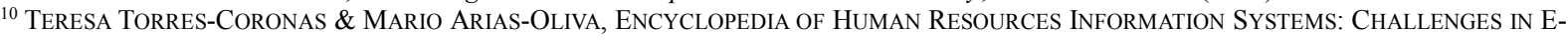
HRM 115-124 (2 ed. 2009).

${ }^{11}$ Shahla F. Ali, Principles of Consumer Financial Dispute Resolution in a Global Context, CONSUMER FIN. DisP. RESOL. IN A COMP. CONTEXT 17 (2011).

${ }^{12} I d$. at 4.
} 
Arbitration differs from a trial in that the parties are not required to follow rules of evidence, and in some cases the arbitrator does not have to apply the governing law. After weighing the details of the dispute from each party's side the arbitrator issues a decision, which in some cases is accompanied by a written explanation or opinion (normally called the "award"). ${ }^{1}$ If the parties have agreed to a binding arbitration, the court can enforce an arbitrator's decision. Only in rare cases is the arbitrator's decision reviewed by the court and refused enforcement.

While ODR has spread due to the growth of e-commerce, the resolution process can become more complex when the e-dispute is between parties across borders. The number of cross border e-disputes is so far relatively low, except in the European Union (EU). ${ }^{2}$ There, e-disputes are more common given that the Euro is the common currency and the EU is a single market. ${ }^{3}$ In 1999, the Organization for Economic Co-operation and Development (OECD) published the "Guidelines for Consumer Protection in the Context of Electronic Commerce," 4 which encouraged business enterprises, governments, and consumer representatives to work together in order to provide consumers - without undue burden or cost - with an opportunity for meaningful access to fair and timely alternative dispute redress and resolution. In the EU, this issue is addressed in the European "Directive on Electronic Commerce." The first part of article 17 of this directive provides:

The member states shall collectively ensure that their extant legislations do not hinder the use of out-of-court systems, available under their respective national laws, for dispute resolution, 'including suitable electronic means', in the event of dispute between any Information Society service provider and the recipient or recipients of the service. ${ }^{6}$

\section{Dispute Resolution Oversight in Saudi Arabia}

Ruled by King Salman bin Abdulaziz Al-Saud, Saudi Arabia is an Islamic monarchy with a unique legal system. The Kingdom's law has a modified civil code system, which is based on Islamic Shari'a. ${ }^{7}$ This system claims its genesis in the Holy Quran, the primary Islamic text based on the teachings of the Prophet Mohammed. The Shari'a legal system is founded on scholarly interpretation of the Quran, rather than on precedent based on court decisions or legislation. As such, each case involving Saudi Arabia will be deliberated upon by referring to the totality of the circumstances governed by the teachings of the Quran and interpreted in accordance with scholarly sources. ${ }^{8}$

Therefore, the Saudi Arabian law governing dispute resolution must be in accord with Shari'a law as the principal law of the Kingdom, as stipulated in Article 7 of the Basic Law of 1992 (the Basic Law). ${ }^{9}$ Saudi Arabia does have established regulations that in most common and civil law systems would be called laws. However, unlike Shari'a law - which is exclusively based on Islam - the Saudi regulations are normally promulgated or enacted as either royal decrees or ministerial resolutions. ${ }^{10}$ These government-formulated regulations supplement Shari'a law regarding day-to-day activities in the Kingdom. They address specific subjects - for example, formation and operation of companies, cybercrime, and dispute resolution. ${ }^{11}$

In the Islamic world, the legality of a regulation depends on its capacity to adhere to Shari'a law. Regulations that do not align with Shari'a law are considered unlawful. ${ }^{12}$ Similarly, an agreement or even an individual provision is considered unenforceable if it violates Shari'a law when the contract is made. In Saudi Arabia, no matter how trivial a dispute might be, no court would issue a verdict that contradicts Islamic principles even if the parties to an agreement would have consented. ${ }^{13}$

\footnotetext{
${ }^{1}$ Anne Hartl, Online Dispute Resolution, THE LAW OF THE FuTURE: 9 (2012). Online Dispute Resolution: Reports and Statistics, EUROPEAN https://ec.europa.eu/consumers/odr/main/?event=main.statistics.show(https://ec.europa.eu/consumers/odr/main/?event=main.statistics.show. ${ }_{3}^{3}$ Pablo Cortés, Council Directive 2013/11/EU, On Alternative Dispute Resolution for Consumers and Regulation (EC) 524/2013, On Online Dispute Resolution, EU Regulation of E-Commerce 233 (2013).

${ }^{4}$ Gilbert Johnson, OECD Guidelines for Consumer Protection in the Context of Electronic Commerce, STUDENTS, COMPUTERS AND LEARNING - MAKING THE CONNECTION - EN - OECD (Mar. 12,1999, 12:17 AM), http://www.oecd.org/sti/consumer/oecdguidelinesforconsumerprotectioninthecontext ofelectroniccommerce1999.htm.

${ }_{5}^{5}$ Pablo Cortés, Council Directive 2013/11/EU, On Alternative Dispute Resolution for Consumers and Regulation (EC) 524/2013, On Online Dispute Resolution, EU Regulation of E-Commerce 234 (2013).

${ }^{6}$ Id. at 237.

${ }^{7}$ M. Q. Zaman, Review: Islamic Law and Legal System: Studies of Saudi Arabia * Frank E. Vogel: Islamic Law and Legal System: Studies of Saudi Arabia, 13 J. OF ISLAMIC STUD. 51 (2002).

${ }^{8} I d$. at 53 .

${ }^{9}$ Saudi Arabia: Royal Decree No. M / 11, 9 Arab L. Q. 292 (1994).

${ }^{10}$ Saud Al-Ammari \& Timothy Martin, Arbitration in the Kingdom of Saudi Arabia, 30(2) ARB. INT'L 389 (2014).

${ }^{11}$ Nathalie Tocci, The EU And Conflict Resolution: Promoting Peace in the Backyard 28 (2008).

${ }^{12}$ Ayoub M. Al-Jarbou, Judicial Independence: Case Study of Saudi Arabia, 19 ARAB L. Q. 27 (2004).

${ }^{13}$ Article 48 of the Basic Law requires courts to apply Islamic Shari'a principles to cases presented before them, with regard for the stipulations of the Holy Koran and the Prophet in addition to other regulations dictated by the head of state in strict adherence to the Holy Koran and the Prophet.
} 
In general, the principle of stare decisis ${ }^{1}$ is not recognized in Saudi Arabia and the courts' decisions cannot establish a binding precedent for resolving later cases. ${ }^{2}$ Some court decisions, however, have recently become available for review online. These include the decisions made by the Board of Grievances in accordance with Article 71 of the Board of Grievances Law, ${ }^{3}$ as issued by Royal Decree No. 78/M. ${ }^{4}$

\section{A. The Board of Grievances}

The Board of Grievances is one of Saudi Arabia's unique dispute resolution mechanisms. Initially, this body was established to address cases relating to the government and its agencies, and had historical jurisdiction over administrative disputes and government contracts. Established in 1982, the board was designed to be an "independent administrative judicial commission," making it directly answerable to the king of Saudi Arabia. ${ }^{5}$ The decree gave the board jurisdiction over appeals to implement foreign judgments, some disputes involving the government, and certain criminal cases and commercial matters. ${ }^{6}$

Recently, a Board of Grievances law reformed the board by establishing specialized administrative tribunals to address the administrative disputes emanating from contracts, administrative decisions, employees, and disciplinary actions, as well as appeals to enforce foreign rules. ${ }^{7}$ The law empowers the "new" board to also determine disputes involving the government. ${ }^{8}$

\section{B. Transition to Court Administration}

The board, however, no longer has jurisdiction over various commercial disputes. Those cases are now decided by newly constituted general courts. The procedure for resolution adopted by these courts is the same as that employed by the board. Further, in a move to streamline dispute resolution, in 2017 the Board of Grievances launched an electronic system for the Supreme Administrative Court to facilitate electronic registration, transfer, and receipt of complaints by the Administrative Appeal Courts, both to and from the Supreme Administrative Court. ${ }^{9}$ This electronic system is a useful and practical precedent for gaining familiarity with online systems for dispute resolution.

\section{Frameworks for Alternative Dispute Resolution Procedures in Saudi Arabia}

Rather than the courts or the Board of Grievances, arbitration is the primary avenue in Saudi Arabia through which traditional commercial disputes are resolved. ${ }^{10}$ Even so, arbitration is currently and largely under the control of the Saudi Centre for Commercial Arbitration (SCCA) in Riyadh. Some of the participants in disputes prefer the SCCA for solutions to their disputes due to the simplicity of the process involved. Although the SCCA has in a way been operational for a long time, acting under the auspices of the Ministry of Justice (where only small cases could be submitted, not exceeding 200,000 SAR), in 2016 it was formally launched as an independent institution after the issuance of Cabinet Decree no. 257, dated March 15, 2014. ${ }^{11}$ The re-established SCCA was tasked with developing procedures for traditional (off-line) arbitrations, administering arbitrations under these rules, and doing so in compliance with Shari'a law, which also facilitates enforcement of arbitration awards produced by the SCCA - particularly concerning civil and commercial disputes.

The involved parties, however, have to agree - whether through an arbitration clause in a contract, or by agreement at the time a dispute arises - to refer their case to this body according to the extant regulations and judicial principles of civil and commercial procedures. Although SCCA can adjudicate various cases brought before it, criminal and administrative disputes are excluded from its jurisdiction. Importantly, the SCCA through its website has signaled that it is working on online dispute resolution procedures - supported by the Saudi government, which is expected to issue the Online Dispute Resolution Protocol in April of 2019 - which will address small dispute under 200,000 SAR. ${ }^{12}$

In light of economic developments and the impact on ensuing legislative changes, the Kingdom issued a

\footnotetext{
${ }^{1}$ The legal principle of determining points in litigation in accordance with precedent.

2. Ayoub M. Al-Jarbou, Judicial Independence: Case Study of Saudi Arabia, 19 ARAB L. Q. 31 (2004).

${ }^{3}$ Article 71 of the Board of Grievances Law states that the Saudi laws shall be published in the Official Gazette, but shall remain ineffective until the date of publication unless stipulated otherwise therein. See Ayoub M. Al-Jarbou, The Saudi Board of Grievances: Development and New Reforms, 25 ARAB L.Q. 177-202 (2011)

${ }^{4}$ Caroline Montagu, Civil Society and the Voluntary Sector in Saudi Arabia, 64 THE MiddLE EAST J. 68 (2010).

${ }^{5}$ Saudi Arabia: Royal Decree No. M/51, 9 Arab L.Q. 292-293 (1994); Damian Taylor, 1 THE DisPUTE RESOLUTION REVIEW 107 (2017).

${ }^{6}$ In 1987, the power to settle certain commercial disputes was transferred to the Board of Grievances pursuant to a resolution of the Council of Ministers No. 241, 26/10/1407 AH.

${ }^{7}$ Damian Taylor, The Dispute Resolution Review (10th ed., Law Business Research Ltd, 2018).

${ }^{8}$ Id. at 402; see also Matthew P. Tucker, An Overview of Alternate Dispute Resolution Use in the Construction Industry, NEGOT. J. 89-92 (2005) ("There are also newly constituted general courts taking jurisdiction over commercial disputes previous handled by the Board of Grievances. The courts, however, follow similar procedures as those followed by the Board.")

${ }^{9}$ Ayoub M. Al-Jarbou, Judicial Independence: Case Study of Saudi Arabia, 19 ARAB L. Q. 177-182 (2004).

${ }^{10}$ Abdullah Sirajuddin, Construction Dispute Resolution in Saudi Arabia Using the "Dispute Resolution Board," 16 J. OF KING ABDULAZIZ UNIVERSITY-ENG'G SCI. 97 (2005).

${ }^{11}$ John Balouziyeh, Judicial Reform in Saudi Arabia: Recent Developments in Arbitration and Commercial Litigation (Dec. 31, 2017), arbitrationblog.kluwerarbitration.com/2017/12/31/judicial-reform-saudi-arabia-recent-developments-arbitration-commerciallitigation/?print=pdf.

${ }^{12}$ See the SCCA website at https://www.sadr.org/ADRServices-arbitration-ODR?lang=en (last visited Mar. 21, 2019).
} 
new Saudi arbitration law in 2012 intended to replace the Arbitration Act $1983 .{ }^{1}$ The new 2012 law provided much needed procedural guidance, which was further supported by detailed regulations - the Saudi Executive Regulations for the Arbitration System - which came into effect in June of 2017. ${ }^{2}$ The 2012 law was intended to provide a detailed road- map for the procedures of traditional (off-line) arbitration, as well as to clarify the competence of the Saudi courts to address and support arbitration. This new law was intended to fill a critical gap, as Saudi Arabia has had few rules or regulations to deal with dispute resolution through arbitration. However, the following areas still cannot be arbitrated: family or labor (employment) disputes. ${ }^{3}$

With the current advances in technology, particularly the internet, some traditional activities pertaining to dispute resolution are also being replaced. The new advancements in information technology have penetrated the legal business aspects in Saudi Arabia, mainly in international commercial arbitration. ${ }^{4}$ Some multinational companies in the Kingdom and abroad have sought to resolve their disputes via mediation and electronic arbitration. These disputes get mired in the complexities and uncertainties of the Saudi legal system, grounded in Shari'a, and as yet are less flexible for resolving international arbitration disputes - particularly those involving online business transactions.

It is therefore important to suggest changes to commercial law in Saudi Arabia and consider how to apply traditional commercial arbitration principles to an online format in the Kingdom. In Saudi Arabia, and in any online form of Saudi arbitration, traditional commercial arbitration in light of international conventions is dependent on three factors. The first is the preservation of the general provisions as well as the principles of commercial arbitration. The second is that the parties must be familiar with the content and procedures of arbitration. The third is the successful translation into electronic (online) means of the necessary principles and procedures found in traditional arbitration. ${ }^{5}$

\section{Key Challenges facing Online Dispute Resolution in Saudi Arabia}

In theory, ODR entails a clear-cut process where aggrieved parties rely on digital technology to arrive at a solution to their conflicts. ${ }^{6}$ This provides an avenue through which individuals can circumvent the jurisdictional difficulties commonly associated with territorially limited courts. ${ }^{7}$ This unique arrangement, however, does leave gray areas that need to be addressed if ODR is to retain its prominent role in sustaining the growth of ecommerce.

\section{A. Lack of Awareness}

Despite its growing role, ODR remains a less popular avenue of handling disputes. ${ }^{8}$ One reason for this lack of popularity is that mainly professionals, rather than the general public, consume ODR services. Since ecommerce companies tend to use these systems more than the public, most methods of marketing these services are targeted toward the professionals. This leaves the public with little information about this important alternative dispute resolution mechanism. ${ }^{9}$ There is an urgent need to sensitize the public to ODR to expand the uptake of these services. One way to embrace the use of ADR and to increase awareness is to encourage public institutions and government institutions to uphold and recommend its use. This can be fueled by the publication of ODR success stories to build the public confidence in this process.

\section{B. Perceived Lack of Legitimacy}

The traditional method of resolving disputes through courts of law remains a jealously protected process and any

\footnotetext{
${ }^{1}$ See the Arbitration Law issued by the Council of Ministers pursuant to Royal Decree M/34 (Apr. 4, 2012) and published in the Official Gazette on June 8, 2012, replacing the Arbitration Law issued pursuant to Royal Decree No. M/46 (Apr., 24, 1983). An English translation of the Arbitration Law is available at http://www.wipo.int/edocs/lexdocs/laws/en/sa/sa057en.pdf; see also Mohammad Al-Suhaibani, Book Review: Islamic Law and Legal System: Studies of Saudi Arabia by Frank Vogel, SSRN ELEC. J. 899 (2001).

${ }^{2}$ See The Kingdom of Saudi Arabia's Implementing Regulations of the 2012 Arbitration Law entered into force - on 22 May 2017 , the Kingdom of Saudi Arabia passed the Implementing Regulations of the 2012 Arbitration Law ("Implementing Regulations"). These regulations came into force on June 9, 2017, after publication in the Saudi Gazette of the Saudi Cabinet Decision No. 541/1438 approving the Implementing Regulations.

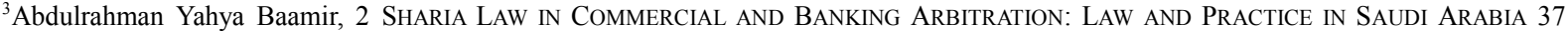
(Routledge 3 ed. 2016). Under the 1982 Arbitration Act, disputes between a Saudi distributor and its principal (a party authorizing an agent to create legal relationships with a third party) were not permitted to be arbitrated. However, this has changed with the 2012 law and these disputes can now go to arbitration.

${ }^{4}$ Perry Cammack, Examining the United States-Saudi Arabia Relationship, 18 GEO. J. OF INT'L AFF. 76-82 (2017).

${ }^{5}$ Arno R. Lodder \& John Zeleznikow, A Three-Step Model for Online Dispute Resolution, ENHANCED DisPUTE RESOLUTION THROUGH THE USE OF INFORMATION TECHNOLOGY 157 (2005). An interesting domestic example of the Kingdom's foray into electronic management of disputes was in 2014, when the Saudi Arabian Ministry of Justice launched new traffic courts primarily located in Mecca, Medina, and Riyadh, as well as the Eastern Province. The courts were designed to resolve disputes emanating from traffic accidents and all the violations were electronically linked to the General Directorate of Traffic.

${ }^{6}$ Frederic BACHAND \& FABIEN GÉlinAs, The UNCITRAL Model LAW AFter Twenty-Five YeARs: Global Perspectives on INTERNATIONAL COMMERCIAL ARBITRATION 253 (Juris Publ'g, Inc. 2013).

${ }^{7}$ Marketa Trimble, Proposal for an International Convention on Online Gambling, 17 (Scholarly Works, Paper 698) (2012).

${ }^{8}$ Pablo Cortés, Council Directive 2013/11/EU, On Alternative Dispute Resolution for Consumers and Regulation (EC) 524/2013, On Online Dispute Resolution, EU Regulation of E-Commerce 15 (2013).

${ }^{9}$ Graham Ross, Challenges and Opportunities in Implementing ODR, in PROCEEDINGS OF THE UNECE FORUM ON ODR 1 (2003).
} 
encroachments to the status quo tend to face hurdles. ${ }^{1}$ Therefore, there can be a tension between conventional dispute resolution and alternative dispute resolution. ${ }^{2}$ The questions about the legitimacy of ODR emanated from its onset, when these dispute resolution channels lacked the key structures typically needed to arrive at legitimated decisions. For example, ODR's private process of handling disputes raised initial fears that the process could be manipulated to suit one party over the other. ${ }^{3}$ Likewise, the lack of conventional brick and mortar locations, where the aggrieved parties and the arbiter have a physical setting in which to meet face to face, compounded the legitimacy concerns.

It is worth noting, however, that ODR panels - just like conventional courts - rely on common law. Common law, originating in England during the Middle Ages under Edward I, provides an interesting jurisdictional perspective for modern times, given its historical practice. ${ }^{4}$ In the past, merchants who travelled across different countries for trade would rely on a variety of courts to access justice and fairness regarding disputes. ${ }^{5}$ Over time, royal English courts took charge of dispute resolution within England. Foreign merchants trading within that country and Europe then lost other avenues for dispute resolution. ${ }^{6}$ The advent of a territorially limited court system using common law weakened global trade, as it favored trades and transactions taking place within well-defined jurisdictions.

The advent of ODR writes a new jurisdictional chapter in common law dispute resolution, as it integrates into the current system of justice bound by national borders or trading blocs. ${ }^{7}$ With the internet erasing physical trade borders, there is a need for a neutral dispute resolution platform without boundaries. ${ }^{8}$ A global jurisdiction using common law is now possible with ODR, marking an evolution for international trade. The uniqueness of this approach, however, leaves it susceptible to concerns about legitimacy.

\section{C.Lack of Comprehensive Government Regulation and Legal Certainty}

The use of alternative arbitration to settle online disputes has created a perception among some that the internet is separate from the laws and regulations of different governments. ${ }^{9}$ Over time, this has become a challenge facing ODR. The present, fast-paced movement of technology and commerce has tested lawmakers to keep up with innovation and has made national legal institutions grapple to establish effective rules. ${ }^{10}$ All these moving parts leave an aura of legal uncertainty. Existing laws are ineffective, imprecise, or too broad to satisfy their regulatory role. $^{11}$

As discussed, the fact that ODR exists in a world without conventional physical boundaries makes tracking different jurisdictional needs a key challenge. For ecommerce transactions and dispute resolution to take place, there needs to be legal certainty that the industry is well regulated. ${ }^{12}$ For ODR specifically to act efficiently it needs well-understood and stable legal norms. ${ }^{13}$ That stability needs to correspond with the evolving needs of the markets and to be able to respond to disruptive technologies and new players. ${ }^{14}$

Since its inception ODR has had to tackle the perception that the internet world exists in a sphere of different laws and regulations than the ones used in traditional dispute resolution. ${ }^{15}$ This perception has, over time, proved a major challenge to the acceptance and uptake of ODR. Furthermore, the fact that ODR emerged when information technology was undergoing major shifts means that traditionally bureaucratic government institutions still struggle to understand the role of alternative dispute resolution. ${ }^{16}$ This kind of environment has created a penumbra of legal uncertainty with traditional laws too broad or imprecise to deal with the dynamic nature of ecommerce disputes. ${ }^{17}$

That situation is compounded by ODR's place in a multijurisdictional environment. Legal uncertainty can

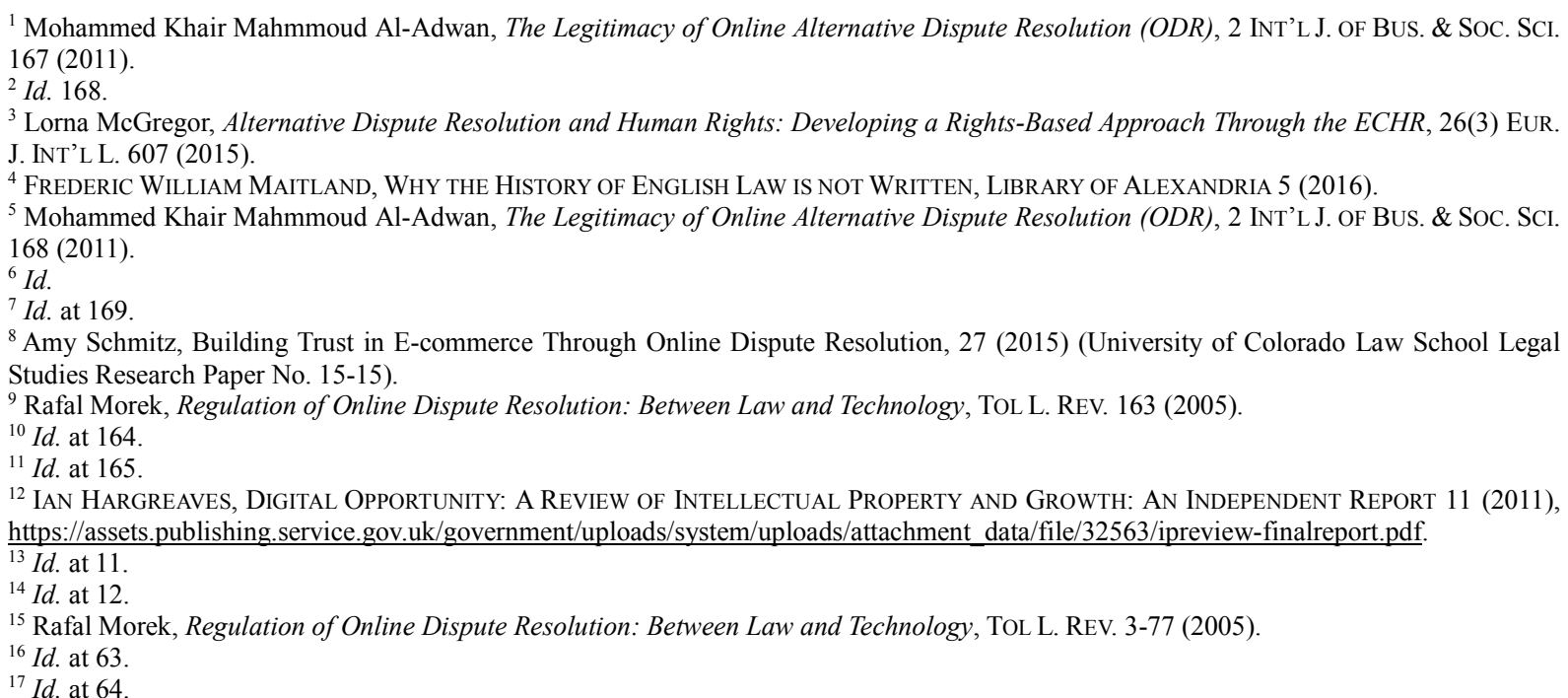


also arise when the conflicting parties subscribe to different legal, religious, or historical beliefs. Added to this is the fact that ODR operates outside the physical boundaries of the conventional world, and keeping up with different jurisdictional needs remains a key challenge. In order for transactions and dispute resolution to take place, there needs to be legal certainty and the assurance that the industry is well regulated. ${ }^{1}$ The markets and the dispute resolution channels that serve them need to be stable for ODR to act efficiently. ${ }^{2}$

ODR's reliability should correspond with the ever-evolving needs of the markets, including the possibility of disruptive technologies or the entry of new players. ${ }^{3}$ Therefore, in order for ODR to grow there is a great need to address the different gray areas ranging from mistrust to multijurisdictional, multicultural, and instability challenges. This response - coupled with heightened sensitization of the public - would expedite the eventual growth of the ADR systems across the globe.

\section{D.Security}

Because alternative dispute resolution for ecommerce relies on computing technology, it also benefits from the continued interest in the protection of data and systems from malfeasance. As the internet has developed, new forms of threats have constantly been discovered, creating a greater need for better security management procedures. $^{4}$ Inadequate internet security - particularly for personal data and confidentiality - remains a challenge. $^{5}$ This has a direct bearing on the establishment of ODR and ADR. ${ }^{6}$

Ecommerce involves parties who do not physically meet or build a rapport prior to engaging in a transaction, so the modalities through which data is transmitted, stored, and shared are vital to protect. This obviously affects ODR, and the relevant practitioners have made strides to improve the privacy of data shared during mediation processes. $^{7}$ In this regard, "security" refers to a safe environment where participants in the process are assured of both emotional and physical safety. ${ }^{8}$

ODR separates parties physically, thus reducing the risk of physical insecurity. Personal security protects users from emotional or physical harm. For this reason, ODR is quite useful in cases where there is a possibility of violence when solving disputes. ${ }^{9}$

ODR systems offering added security alongside transparency and fairness can provide a further sense of emotional security. ${ }^{10}$ The systems and parties involved in this process constantly acknowledge the need to safeguard the privacy of information utilized in the course of resolving the dispute. ${ }^{11}$ Specifically, ODR typically entails the utilization of software and communication channels that can be tweaked to bolster data security. Despite these advances, however, the internet world generally remains porous in securing data transmission. ${ }^{12}$ As such, if ODR is to retain its prominent role in ecommerce then there need to be clear-cut laws and measures to safeguard data security and confidentiality.

Data security protects data around communication channels, servers, software, and hardware used for ODR. This is to prevent third parties from hacking and accessing business or individual information. The wide range of protected data includes pictures and arbitration information. ${ }^{13}$

System security addresses the users' confidence in the ODR service they choose. That confidence can be improved by ensuring that the information provided to the technological platform is not being exposed. Companies must ensure that the parties' data is not being sold, revealed, or used in any way. ${ }^{14}$

Increasingly, businesses have developed resources for protecting their interests on an ODR platform. Clients of these companies, however, typically do not have the resources and sophistication to protect themselves. Individuals might also lack incentives and resources to pursue claims against companies. ${ }^{15}$ Nonetheless, overall strategies are growing for widespread information security, data security, personal security, and system security.

Information security for the ODR process includes inherent ways to protect individual parties' information from being shared by outsiders. These include a duty for the mediator to keep what he or she has learned from reaching third parties, parties' contracted to protect that information from third parties, and legal requirements to

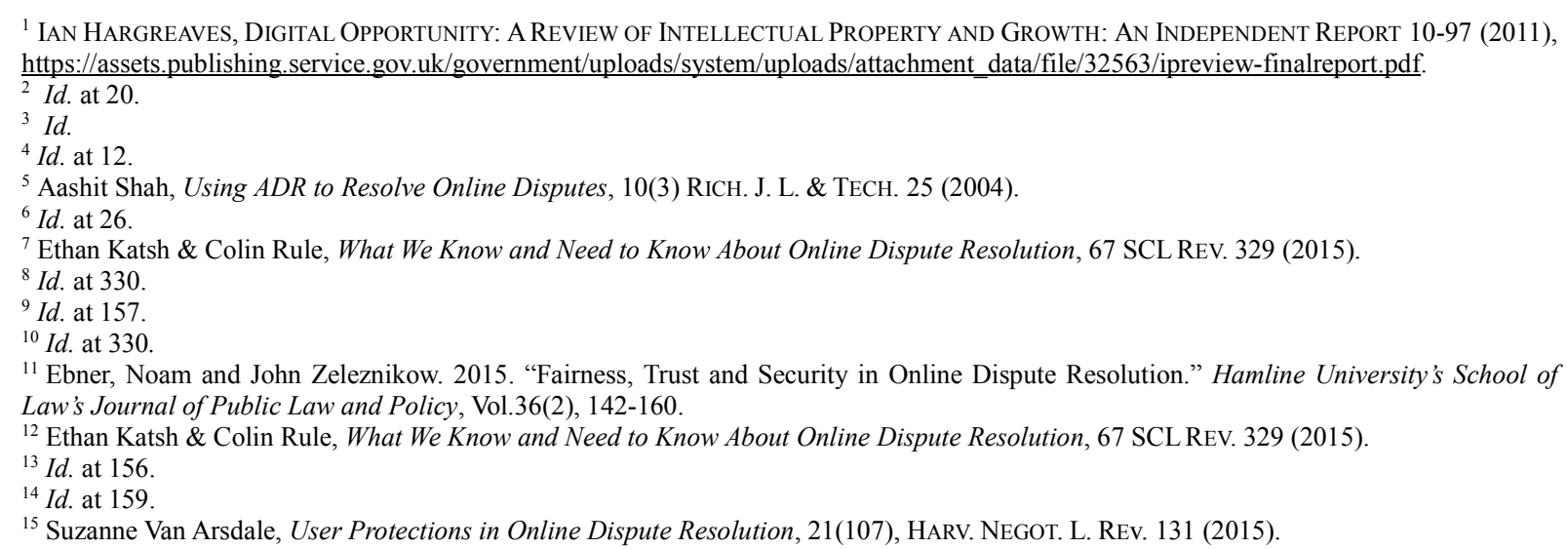


protect information during a legal process. ${ }^{1}$

Users of an ODR platform are also protected. Businesses usually have resources to protect their interests, but individual users or consumers may lack the resources, opportunities, or sophistication to make the right choices. Furthermore, individual users may lack incentives or resources to pursue claims against platforms or businesses. For this reason, there are protections that have been created for users. For instance, codes of practice and standards for ODR are used for the protection of users. Important features of dispute resolution processes that include arbitration, mediation, and collaborative laws are standardized in many states. The American Bar Association (ABA) Section of Dispute Resolution offers codes of ethics, standards of conduct, best practices, and more. ${ }^{2}$

Many certifiers and providers have established codes of practice and process protocols to create a baseline of fairness in arbitration and other ADR clauses. Institutions can request a waiver if a different dispute resolution does not comply with the protocols of an institution. However, the protocols are seen to lack a monitoring and enforcement mechanism, especially because of under-enforcement of the consumer protection regulations.

Another approach for protecting users involves using accreditation that includes a directory or guide, an evaluator, certifiers, an implementer, and judicial review. Accreditation is an information and trust service that users can use to make the right choices. In 2002, the ABA Task Force on Electronic Commerce and ADR recommended the establishment of an entity tasked with education and information of consumers, businesspersons, and lawyers about relevant issues. With the accreditations consumers can utilize systems like a directory, which is a compilation of ODR platforms or providers and the information about them. Governments have also offered directories. ${ }^{3}$ For instance, in 2005 the US Federal Trade Commission and consumer protection agencies in 20 countries established an international ADR directory that offered consumers information about a neutral provider to help them solve cross-border ecommerce disputes. ${ }^{4}$

\section{Conclusion}

Online dispute resolution plays a critical role by using technology to expedite access to fair arbitration and mediation processes. This ultimately enhances and encourages ecommerce. However, as we have seen in this analysis, there is still room for improvement by streamlining the existing domestic and international laws, treaties, and conventions to harmonize the growth of online dispute resolution as a valid method of settling disputes faster and more conveniently.

Significantly, the effective adoption of alternative dispute resolution is still important to champion in conservative countries like Saudi Arabia. The challenge there lies in the consistent use of Shari'a law and reliance on bodies like the Board of Grievances to settle disputes. It is critical to analyze the legal challenges and opportunities in order to uncover new potential for third party, private mediation services across the globe as ODR plays an important role.

\section{REFERENCES}

Julia Hornell, Internet Disputes, Cross-Border Internet Dispute Resolution 19-46 (2009).

Farzaneh Badiei, Using Online Arbitration in E-Commerce Disputes, 2 INT'L J. ON ONLINE DISP. Resol. 13 (2015).

Kenneth McCulloch, Alternative Dispute Resolution Techniques: Pros and Cons, 11 EMP. REL. TODAY 311-319 (1984).

Karolina Mania, Online Dispute Resolution: The Future of Justice, 1 INT’L COMP. JURIS. 77 (2015).

Stephanie Bol, Ethan Katsh \& Janet Rifkin, Online Dispute Resolution, Resolving Conflicts in Cyberspace, 11 ARTIFICIAL INTELLIGENCE \& L. 69 (2003).

Benyekhlef Karim \& Gélinas Fabien, Dispute Resolution, A MANUAL OF InTERnATIONAL Dispute Resolution 13 (2006)

Julie Zetler, Litigation and Dispute Resolution, Essentials of Law, Ethics, AND Professional Issues IN CAM 45 (2012).

Daniel Bar-Tal, From Intractable Conflict through Conflict Resolution to Reconciliation: Psychological Analysis, 21 POL. PSYCHOL. 353 (2000).

Osama Jannadia et al., Contractual Methods for Dispute Avoidance and Resolution (DAR), 18 INT'L J. OF PROJECT MGMT 43 (2000).

Jacques De Werra, ADR in Cyberspace: The Need to Adopt Global Alternative Dispute Resolution Mechanisms

\footnotetext{
${ }^{1}$ Ebner, Noam and John Zeleznikow. 2015. "Fairness, Trust and Security in Online Dispute Resolution." Hamline University's School of Law's Journal of Public Law and Policy, Vol.36(2), 156.

${ }^{2}$ Suzanne Van Arsdale, User Protections in Online Dispute Resolution, 21(107), HARV. NegOT. L. REv. 137 (2015)

${ }^{3} I d$. at 138

${ }^{4} I d$. at 138
} 
for Addressing the Challenges of Massive Online Micro-Justice, 2 SSRN ELEC. J. 81 (2016).

Stephanie Bol, Ethan Katsh \& Janet Rifkin, Online Dispute Resolution, Resolving Conflicts in Cyberspace, 11 ARTIFICIAL INTELLIGENCE \& L. 70(2003).

Tania Sourdin \& Alan Shanks, Evaluating ADR in ATO Disputes -- Executive Summary, SSRN ELEC. J. 61 (2015).

TERESA TORRES-CORONAS \& MARIO ARIAS-Oliva, ENCYClOPEDIA OF HuMAN RESOURCES INFORMATION SYSTEMS: CHALLENGES IN E-HRM 115-124 (2 ed. 2009).

Shahla F. Ali, Principles of Consumer Financial Dispute Resolution in a Global Context, ConsuMER FIN. DISP. RESOL. IN A COMP. CONTEXT 17 (2011).

Anne Hartl, Online Dispute Resolution, THE LAW OF THE FUTURE: 9 (2012).

Online Dispute Resolution: Reports and Statistics, EUROPEAN COMMISSION, https://ec.europa.eu/consumers/odr/main/?event=main.statistics.show(https://ec.europa.eu/consumers/odr/ main/? event=main.statistics.show

Pablo Cortés, Council Directive 2013/11/EU, On Alternative Dispute Resolution for Consumers and Regulation (EC) 524/2013, On Online Dispute Resolution, EU Regulation of E-Commerce 233 (2013).

Gilbert Johnson, OECD Guidelines for Consumer Protection in the Context of Electronic Commerce, STUDENTS, COMPUTERS AND LEARNING - MAKING THE CONNECTION - EN - OECD (Mar. 12,1999, 12:17 AM), http://www.oecd.org/sti/consumer/oecdguidelinesforconsumerprotectioninthecontext ofelectroniccommerce1999.htm.

M. Q. Zaman, Review: Islamic Law and Legal System: Studies of Saudi Arabia * Frank E. Vogel: Islamic Law and Legal System: Studies of Saudi Arabia, 13 J. OF IsLAMIC STUD. 51 (2002).

Saud Al-Ammari \& Timothy Martin, Arbitration in the Kingdom of Saudi Arabia, 30(2) ARB. INT'L 389 (2014).

Nathalie Tocci, The EU And Conflict Resolution: Promoting PeACE IN THE BACKyARd 28 (2008).

Caroline Montagu, Civil Society and the Voluntary Sector in Saudi Arabia, 64 THE MidDLE EAST J. 68 (2010).

Damian Taylor, THE DisPute RESOLUTION REVIEW (10th ed., Law Business Research Ltd, 2018).

Matthew P. Tucker, An Overview of Alternate Dispute Resolution Use in the Construction Industry, NEGOT. J. 89-92 (2005).

Abdullah Sirajuddin, Construction Dispute Resolution in Saudi Arabia Using the "Dispute Resolution Board," 16 J. OF KING ABDULAZIZ UnIVERSITY-EnG'G SCI. 97 (2005).

John Balouziyeh, Judicial Reform in Saudi Arabia: Recent Developments in Arbitration and Commercial Litigation (Dec. 31, 2017), arbitrationblog.kluwerarbitration.com/2017/12/31/judicial-reform-saudi-arabiarecent-developments-arbitration-commercial-litigation/?print=pdf.

Abdulrahman Yahya Baamir, 2 SHARIA LAW IN COMMERCIAL AND BANKING ARBITRATION: LAW AND PRACTICE IN SAUDI ARABIA 37 (Routledge 3 ed. 2016).

Perry Cammack, Examining the United States-Saudi Arabia Relationship, 18 GEO. J. OF INT’L AFF. 76-82 (2017).

Arno R. Lodder \& John Zeleznikow, A Three-Step Model for Online Dispute Resolution, ENHANCED DISPUTE RESOLUTION THROUGH THE USE OF INFORMATION TECHNOLOGY 157 (2005).

Frederic Bachand \& Fabien Gélinas, The UNCITRAL Model LaW after Twenty-Five Years: Global PERSPECTIVES ON INTERNATIONAL COMMERCIAL ARBITRATION 253 (Juris Publ'g, Inc. 2013).

Marketa Trimble, Proposal for an International Convention on Online Gambling, 17 (Scholarly Works, Paper 698) (2012).

Graham Ross, Challenges and Opportunities in Implementing ODR, in PROCEEDINGS OF THE UNECE FORUM ON ODR 1 (2003).

FREDERIC William Maitland, Why the History OF ENGLish LAW IS NOT WRITTEN, LiBRARY OF ALEXANDRIA 5 (2016).

Lorna McGregor, Alternative Dispute Resolution and Human Rights: Developing a Rights-Based Approach Through the ECHR, 26(3) EUR. J. INT'L L. 607 (2015).

Mohammed Khair Mahmmoud Al-Adwan, The Legitimacy of Online Alternative Dispute Resolution (ODR), 2 INT’L J. OF BUS. \& SOC. SCI. 167 (2011).

Amy Schmitz, Building Trust in E-commerce Through Online Dispute Resolution, 27 (2015) (University of Colorado Law School Legal Studies Research Paper No. 15-15).

Ian Hargreaves, Digital Opportunity: A Review of Intellectual Property and Growth: AN INDEPENDENT $\quad$ REPORT https://assets.publishing.service.gov.uk/government/uploads/system/uploads/attachment_data/file/32563/ipr eview-finalreport.pdf.

Aashit Shah, Using ADR to Resolve Online Disputes, 10(3) RICH. J. L. \& TECH. 25 (2004).

Ethan Katsh \& Colin Rule, What We Know and Need to Know About Online Dispute Resolution, 67 SCL REV. $329(2015)$. 
Ebner, Noam and John Zeleznikow. 2015. "Fairness, Trust and Security in Online Dispute Resolution." Hamline University's School of Law's Journal of Public Law and Policy, Vol.36(2), 142-160.

Suzanne Van Arsdale, User Protections in Online Dispute Resolution, 21(107), HaRV. Negot. L. REv. 131 (2015).

Saudi Arabia: Royal Decree No. M/51, 9 Arab Law Quarterly 292-293 (1994).

The Code of Commercial Court, 'Nizam Almahkamah Altijaiyah' issued by Royal Decree No. 32, 15/01/1350 H (1931).

The Saudi Arbitration Law issued by the Council of Ministers pursuant to Royal Decree M/34 (Apr. 4, 2012) and published in the Official Gazette on June 8, 2012, replacing the Arbitration Law issued pursuant to Royal Decree No. M/46 (Apr., 24, 1983). An English translation of the Arbitration Law is available at https://www.wipo.int/edocs/lexdocs/laws/en/sa/sa057en.pdf. 